\title{
Resource Productivity and Resource Use Efficiency in Chickpea Production
}

\author{
R.V. Chavan*, S.S. More and R.D. Shelke \\ Department of Agricultural Economics \\ Vasantrao Naik Marathwada Krishi Vidyapeeth, Parbhani, India \\ *Corresponding author
}

\section{A B S T R A C T}

\section{Keywords}

Resource

productivity, Use

efficiency, Chickpea

Production

Article Info

Accepted:

xx April 2020

Available Online:

xx May 2020
The pulses are an important source of protein for the poor as well as for the vegetarians. Chickpea is most important pulse crop of India in terms of area and production, widely grown for centuries and accounts for nearly 40 per cent of the total pulse production in the country. Chickpea is most important pulse crop of India in terms of area and production, widely grown for centuries and accounts for nearly 40 per cent of the total pulse production in the country. The data was collected from cultivars with the help of pre-tested schedule through personal interview method. The data pertains for the year 2018-19. In case of resource use efficiency is can be concluded that there was greater opportunity to increase seed, human labour, machine labour, phosphorus, nitrogen, plant protection.

\section{Introduction}

Pulses are cultivated in all parts of the world and occupy an important place in human diet. India, Brazil, China, Turkey and Mexico are major pulses producing countries in the world. The pulses are an important source of protein for the poor as well as for the vegetarians. Pulses are a Smart Food as these are critical for food basket (dal-roti, dalchawal), important source of plant protein and help address obesity, diabetes etc. In addition, pulses are highly water efficient, can grow in drought prone areas and help improve soil fertility by fixing soil nitrogen. The pulses are also a rich source of green and dry fodder for livestock production. Therefore, pulses are important in cropping pattern.

Currently, we are in the mid-way of selfsustaining in pulses production as we are world leader in production, consumption and import as well. India accounts for about 29 per cent of the world area and 19 per cent of the world's production with 25.26 million hectares' area and production of 16.47 million tonnes. As pulse is an integral part of Indian cuisine, there is always a huge demand supply mismatch of pulses in India. Despite India being the largest producer and processor of 
pulses in the world also imports around 3.5 million tons annually on an average to meet its ever-increasing consumption needs of around 22.0 million tons. According to Indian Institute of Pulses Research's Vision document, India's population is expected to touch 1.68 billion by 2030 and the pulse requirement for the year 2030 is projected at 32 million tons with anticipated required annual growth rate of $4.2 \%$. The average productivity of pulses in the country is 781 $\mathrm{kg} / \mathrm{ha}$, which is much below the world's productivity of $871 \mathrm{~kg} / \mathrm{ha}$. Thus, the productivity and production of pulses has remained more or less stagnant for last four decades. Slight increase is observed during last five years showing the impact of National Food Security Mission on pulses.

Madhya Pradesh is the major pulse producing state in the country, both in terms of area $(22.81 \%)$ and production $(31.07 \%)$ followed by Rajasthan area (15.33\%) and production $11.86 \%$ ), Maharashtra (area 13.29\%) and production $8.56 \%)$, Karnataka area $(11.01 \%)$ and production $(8.43 \%)$ and Uttar Pradesh (area $7.38 \%$ and production $7.40 \%$ ). Maharashtra ranks third amongst the Indian states in terms of area and production under pulses. The productivity of pulses in the state is very low (420 kg/ha) as compared to the other leading states.

Chickpea is most important pulse crop of India in terms of area and production, widely grown for centuries and accounts for nearly 40 percent of the total pulse production in the country. India dominates in the global chickpea market as it has the distinction of being the largest producer, consumer and importer of chickpea in the world and accounts for over 64 per cent of the global output. India grows chickpea on about 8.35 million hectares area with 7.17 million tons of grains which represents more than 40 per cent of the national pulse acreage and production respectively.
Keeping in view the above aspects, the present study has been undertaken with following objectives includes to examine the resource productivity and resource use efficiency in production of chickpea

\section{Materials and Methods}

This chapter deals with the blueprint of research and the sources of data. It was intended to describe methodology clearly adopted to accomplish the objective of study.

Multi stage sampling design was adopted for selection of districts, tehsils, villages and chickpea growers. In the first stage, three districts namely Parbhani, Hingoli and Latur were purposely selected from Marathwada region.

In the second stage, from each district two tahsils were selected on the basis of more area under chickpea cultivation. In third stage, list of predominant villages with respect to area under chickpea were obtained from selected tehsils. From each tehsil, two villages were selected purposely.

In the fourth stage, from the list of chickpea growers, ten chickpea growers were randomly selected from each village. In this way, from three districts, one hundred twenty chickpea growers were selected for the present study. The data was collected from cultivars with the help of pre-tested schedule through personal interview method. The data pertains for the year 2018-19.

\section{Results and Discussion}

Resource productivity and resource use efficiency in chickpea

Estimates of Cobb-Douglas production function in chickpea production were presented in Table 1. The findings with respect to elasticity of production, marginal 
productivity, resource use efficiency and optimum resource use are presented as follows.

\section{Elasticity of production}

The result revealed that coefficient of multiple determinations $\left(\mathrm{R}^{2}\right)$ was 0.84 which indicated 84 per cent effect of all independent variables together in chickpea production. Fvalue was 89.49 which is highly significant. Return to scale was 1.42 which indicated increasing trend of return to scale. It was rare in the business of agriculture, possible in shirt run as all resources are not completely utilized.

The results revealed that the regression coefficient of area was 0.394 which is positive and significant at 5 per cent level of significance. The regression coefficient of seed was 0.520 positive and significant at one per cent level. The regression coefficient of plant protection was 0.142 which was positive and significant at 5 per cent level. Thus, there was scope to increase these variables on priority basis. For instance, if one per cent increases seed, the production of chickpea will increase by 0.520 per cent over its geometric mean (49.08)

\section{Marginal productivity}

It was observed that marginal product with respect to area under chickpea was 5.10 quintals which mean that if area under chickpea cultivation is increased by one hectare to geometric mean which cause to increase production of chickpea by 5.10 quintals.

Marginal product of hired human labour was 0.03 quintals it indicated that additional use of one-man day cause to give additional product of chickpea by 0.03 quintals.
Marginal product of machine labour was 0.02 quintals and seed was 0.11 quintals which mean that when there was addition of one hour of machine labour and one $\mathrm{kg}$ of seed it increases chickpea production by 0.02 quintals and 0.11 quintals respectively. Similarly, the marginal product of phosphorus caused to increase the production up to 0.01 quintals. Thus area under chickpea, human labour, machine labour, seed, phosphorous were underutilized resources in chickpea production.

\section{Resource use efficiency}

Resource use efficiency expressed in monetary terms as relationship of marginal value produce and prices of inputs. Results revealed that marginal value product (MVP) of area under chickpea were found to be Rs.24123.00 and price of input of land under chickpea was Rs.12270.27, hence MVP to price ratio was 1.96. Results revealed that marginal value produce (MVP) to price ratio with respect to Human labour, Machine labour, Seed, Nitrogen, Phosphorus and Plant protection was 141.90, 94.60, 520.30, 94.60, $47.30,331.10$ respectively. Expenditure on these resources could be increased for chickpea production.

It was cleared that higher the MVP to price ration there was greater opportunity to increase these resources. The results inferred that there was greater opportunity to increase seed, human labour, machine labour, phosphorus, nitrogen, plant protection.

\section{Optimum resource use}

Results showed that use of area could be increased upto 0.791 hectares in chickpea production. 
Table.1 Estimates of Cobb Douglas production function in chickpea production

\begin{tabular}{|c|c|c|c|c|c|c|c|c|c|c|}
\hline $\begin{array}{l}\text { Sr. } \\
\text { No. }\end{array}$ & Variables & $\begin{array}{c}\text { Partial } \\
\text { Regression } \\
\text { Coefficient } \\
\text { (bi) }\end{array}$ & $\begin{array}{c}\text { Standar } \\
\text { d Error } \\
(\mathrm{SE}+)\end{array}$ & $\begin{array}{c}\text { 't' } \\
\text { value }\end{array}$ & $\begin{array}{l}\text { Geometri } \\
\text { c mean }\end{array}$ & $\begin{array}{c}\text { Marginal } \\
\text { Product } \\
\mathbf{q}\end{array}$ & $\begin{array}{l}\text { Marginal } \\
\text { Value } \\
\text { Product } \\
\text { (MVP) }\end{array}$ & $\begin{array}{c}\text { Price of } \\
\text { Input } \\
\text { (Rs.) }\end{array}$ & $\begin{array}{l}\text { MVP to } \\
\text { price } \\
\text { ratio }\end{array}$ & $\begin{array}{c}\text { Optimum } \\
\text { resource } \\
\text { Use } \\
\text { (Xi) }\end{array}$ \\
\hline 1 & $\begin{array}{l}\text { Area under chickpea } \\
\text { production (ha/farm) }\end{array}$ & 0.394 & 0.155 & $2.539 *$ & 0.791 & 5.10 & 24123 & 12270.27 & 1.96 & 0.791 \\
\hline 2 & $\begin{array}{l}\text { Human labour } \\
\text { manday/farm) }\end{array}$ & 0.135 & 0.088 & 1.546 & 40.676 & 0.03 & 141.90 & 200.00 & 0.70 & ---- \\
\hline 3 & Machine labour (hour/farm) & 0.023 & 0.039 & 0.586 & 10.629 & 0.02 & 94.60 & 500.00 & 0.19 & ---- \\
\hline 4 & Seed (kg/farm) & 0.520 & 0.140 & $3.720 * *$ & 49.008 & 0.11 & 520.30 & 92.00 & 5.65 & 273.76 \\
\hline 5 & Nitrogen (kg/farm) & 0.023 & 0.025 & 0.900 & 11.504 & 0.02 & 94.60 & 13.04 & 7.25 & ---- \\
\hline 6 & Phosphorus(kg/farm) & 0.044 & 0.037 & 1.192 & 26.392 & 0.01 & 47.30 & 39.05 & 1.21 & ---- \\
\hline 7 & Plant protection (L/farm) & 0.142 & 0.030 & $4.715 * *$ & 1470 & 4.67 & 331.10 & 757.29 & 29.16 & 9.08 \\
\hline
\end{tabular}

Intercept $(\log$ a) ------------- -1.289

F value --------------------- 89.49

$\mathrm{R}^{2}$------------------------------ 0.848

Return to scale $\left(\sum \mathrm{b}_{\mathrm{i}}\right)$------ 1.42

* Significant at 5 per cent level

** Significant at 1 per cent level
Note: Geometric mean $(\overline{\mathrm{Y}})$ of chickpea production was $10.24 \mathrm{q} /$ farm and price was Rs.4730.00/q 
Similarly use of seed, plant protection was found to be increased $273.76 \mathrm{~kg}$ and Rs.9.08 for optimum resource use.

It is concluded that in case of resource use efficiency is can be concluded that there was greater opportunity to increase seed, human labour, machine labour, phosphorus, nitrogen, plant protection.

\section{References}

Asmatoddin, M., J.N. Ghulghule, S.V. Jawale and J.B. Tawale, 2009. Resource productivity and resource use efficiency in pulses production on medium farm in Marathwada. Inter. J. Agric. Sci., 5(2): 359-362.

Banta, A.L., J.G. Akpoko, B. Ahmed and J.O. Olukosi, 2013.Resource Use Efficiency in Pigeon Pea (Cajanus cajan L.) Production Under Mixed Cropping Systems In Samaru - Kataf Zone Of Kaduna State Agricultural Development Project (Kadp) Nigeria. Journal of Agricultural Sciences and Policy Research, 3(1): 212-215.
Bondar, U.S., V.D. Waiwal, A.V. Gavali and D.S. Navadkar, 2017. Resource use and cost structure of chickpea production in Maharashtra. Paper presented in International Conference of Maharashtra Society of Agricultural Economics, held at Department of Agricultural Economics, Mahatma Phule Krishi Vidyapeeth, Rahuri, M.S. on 10-11, February, 2017.

Deshmukh, D.S., B.R. Pawar, V.V. Landge and P.P. Yeware, 2010. Resource productivity and resource use efficiency in pearl millet production. International Journal of Commerce and Business Management, 3(1): 117-119.

Gavali, A.V., T.B. Deokate and A.D. Tambe, 2017. Determination of resource use efficiency of pulses in Maharashtra. Paper presented in International Conference of Maharashtra Society of Agricultural Economics, held at Department of Agricultural Economics, Mahatma Phule Krishi Vidyapeeth, Rahuri, M.S. on 10-11, February, 17.

\section{How to cite this article:}

Chavan, R.V., S.S. More and Shelke, R.D. 2020. Resource Productivity and Resource Use Efficiency in Chickpea Production. Int.J.Curr.Microbiol.App.Sci. 9(05): 2997-3001. doi: https://doi.org/10.20546/ijcmas.2020.905.355 